\title{
DEVELOPMENT A MACHINE FOR PICKING CALENDULA INFLORESCENCES TO SUIT THE SMALL HOLDING FARMERS
}

\author{
Tarek H. Mohamed ${ }^{1}$, Sahar E. Mosa ${ }^{1}$ and Tarek O. Hamad ${ }^{2}$
}

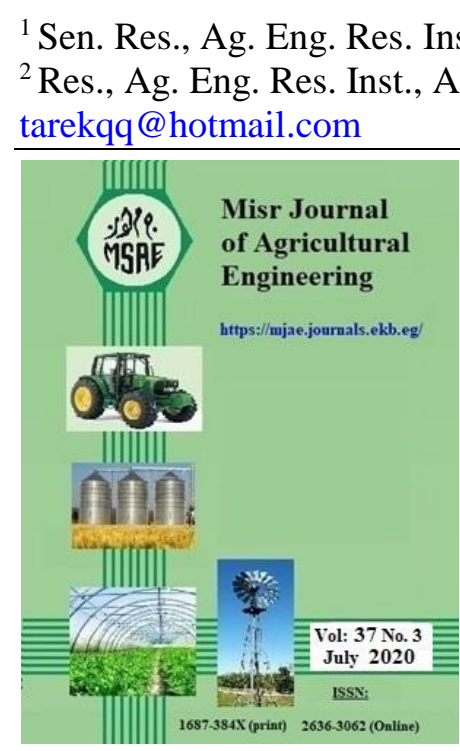

C Misr J. Ag. Eng. (MJAE)

Keywords:

calendula, calendula Picking, Picking comb.

\section{ABSTRACT}

The experiments were carried out at Tamiya, Fayom, Egypt for developing a Calendula inflorescence picking machine suit to the small holding farmers. The machine was consisted of a cutting head and knapsack air vacuum unit. The cutting head was equipped with two saw discs rotating underneath calibration fingers. These fingers were used to measure the correct flowering stem length before cutting. Three types of cutting saw discs (plan,50teeth, and 100 teeth) were used at five disc speeds of 2.78,4.17,5.56,6.97, and $8.34 \mathrm{~m} / \mathrm{s}$ to determine the optimum disc type and disc cutting speed that fitful a higher ratio of correct cutting stem length. Also, the same procedures were made with the optimum disc linear speed $6.97 \mathrm{~m} / \mathrm{s}$, and 100 teeth discs with fingers lengths of $(125 \mathrm{~mm}, 150 \mathrm{~mm}, 175 \mathrm{~mm}$, and $200 \mathrm{~mm})$ at three fingers angles $\left(0^{\circ}, 10^{\circ}\right.$, and $\left.20^{\circ}\right)$. The results indicated that the optimum parameters were at $6.97 \mathrm{~m} / \mathrm{s}$ disc linear speed, 100 teeth discs type, $150 \mathrm{~mm}$ finger length, and finger angle $10^{\circ}$ that gave average percentage of a correct stem cut length $93.31 \%$. The machine productivity at the optimum parameters was $0.0576 \mathrm{Mg} / \mathrm{h}$ from freshly cut flower gave $0.01973 \mathrm{Mg} / \mathrm{h}$ dried flowers. The total operating costs were 33.07 EGP/h. The machine indicated NPV of 2747.24 EGP at 14 $\%$ interest rate, and payback period 1.28 year with rental price $60 \mathrm{EGP} / \mathrm{h}$. The cost of one Megagram of dry crop harvested by the machine was 1676.51EGP/Mg against 7785.89EGP/Mg of the crop collected by hand.

\section{INTRODUCTION}

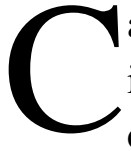
alendula (Calendula officinalis L.) is one of the important medicinal plants cultivated in Egypt. MOALR, (2019) mentioned that on winter season 2018-2019, Egypt cultivated 1087 Feddan of Calendula with productivity of $16560 \mathrm{Mg}$ especially in Fayom and Bani Souf governorates. Calendula inflorescences petals have been used traditionally as culinary and medicinal herbs. The petals are edible and can be used freshly in salads or dried as a tea. Also, a yellow dye extracted from the inflorescences to color cheese instead of saffron. (Khalid \& da Silva, 2012) mentioned that Calendula is widely used in industry and medicine. It is antimicrobial and anti-human immunodeficiency virus actions 
have provoked great attention, increasing the interest for cultivation. (Kisgeci \& Adamovic, 1994) mentioned that Calendula is grown in crop rotation. Propagation is done by direct sowing at the beginning of spring, with a row distance between 400 and $600 \mathrm{~mm}$. The harvested inflorescences should be dried as soon as possible in order to prevent any quality reduction. So, the yield ranges from 800 to $1,500 \mathrm{~kg}$ of dried inflorescences per hectare, but can be even higher in favorable conditions. (Hendawy et al., 2013) stated that the optimum time to harvest Calendula inflorescences when the radial inflorescences axesis parallel to the ground surface. The inflorescences picked from the early morning to evening. The harvesting season in Egypt begin from the middle of December to May. The productivity is 1.5-2 tons per Feddan from dry inflorescences that give 1 ton of dry petals. (Veselinov et al., 2008) mentioned that one of the problems of Calendula production is a high cost of manual harvesting, picking of inflorescences during the flowering period that performed every 3 to 5 days. Hand - mostly belong to the best quality product, with harvested inflorescences stems shorter than $2 \mathrm{~cm}$. However, the picker efficiency is around $4 \mathrm{~kg} \mathrm{~h}^{-1}$ of fresh mass. Due to high requirement of handy labor, manual harvesting becomes a problem in Egypt. Therefore, mechanical harvesting for Calendula is needed. Most of medicinal farmers in Egypt cultivate Calendula in small scale areas not suitable for tractor maneuverability and cultivated it among different kinds of medicinal and aromatic plants. Whereupon, a compact machine is suit for moving between Calendula rows. There are different methods were used to pick Calendula. (Willoughby et al., 2000) developed two different_devices, both based on rotating pairs of picking fingers, but with different cleaning systems. The first uses retraction of fingers into cylinder and doffer brush, whereas the second utilizes a rotor made of music instruments wires for removal of inflorescences trapped by the picking fingers. Both machines are equipped with a separation band for the removal of admixtures. In both solutions, the picking efficiency was up to 80\%. According to (Herold et al. ,1989), (Hecht et al. ,1992), (Dachler and Pelzmann, 1999), (Mohr, 2002), (Zimmer and Müller, 2004) and (Brabandt and Ehlert,2011), inflorescences of chamomile (Matricaria recutita L.), Calendula, and several other medicinal plants can be harvested by machines with the working device known as a rotating comb. (Martinov and Adamovic,2002), (Zimmer and Müller ,2004), (Martinov and Konstantinovic, 2007) stated that the harvest of chamomile and pyrethrum (Pyrethrum cinerariaefolium Trev.) can be performed by the virtual rotating comb type harvester, but (Brabandt and Ehlert ,2011) named "rotating pin drum", with wide tines distance. (Veselinov et al. ,2014) harvested Calendula inflorescences by virtual rotating comb-type chamomile harvester, widely used in South Eastern Europe, and to develop the mechanical separator for the inflorescences from the harvested mass. The impact of coefficient R, ratio of the harvester penetration into inflorescences horizon and the width of inflorescences band (i.e. the average value of the highest and lowest inflorescences span) on the harvest yield, was tested first. It was found that, for coefficient $\mathrm{R}$ (relation between depth of working device penetration into the inflorescences horizon to width of inflorescences band) value of 1.3, an average of $97 \%$ of the total inflorescences yield can be harvested. The proportion of inflorescences with stem length up to $2 \mathrm{~cm}$ was $65 \%$ and $35 \%$ for stems over $2 \mathrm{~cm}$. The result of mechanized harvest was the reduction in both the number of succeeding harvests and the yield, due to bud damages and elimination. The highest separation efficiency was obtained by 
using $2.7 \mathrm{~Hz}$ oscillation frequency and combination of $6 / 8 \mathrm{~mm}$ rods distances in sieves. After three passes of the harvested mass through the device, approximately $92 \%$ of inflorescences were separated.

(Willoughby et al., 2000) designed and constructed a mechanical harvester for marigold inflorescences. Marigold inflorescences are harvested for the xanthophylls pigments found in petals. These yellow-gold pigments are present in the petals at a concentration of 10-100 times that found in other sources. Two different headers were tried. One used extendable fingers mounted in a drum and the other use solid mounted fingers to plunk the flower from the plant. Within two different headers as, the retractable finger drum and the fixed finger header was designed to pick the inflorescences for multiple harvest. The retractable finger header had an overall harvesting efficiency of $18-66 \%$. The fixed finger header had an overall efficiency of $20-72 \%$. The mechanical constraints of retraceable finger drum precede the fixed finger header as the best solution for meeting the objective. The inclined belt separator collected $76-99 \%$ of the inflorescences that were harvested material which adequately meets the second objective.

The aim of this research is developing and testing a machine for harvesting Calendula inflorescences suit to small scale areas with export specifications. The machine should harvest the inflorescences with minimum damage and keep the flowering buds on the plants for several blooming and harvesting visits.

\section{MATERIALS AND METHODS}

\section{(I) Some physical properties for Calendula (Calendula officinalis L.) plants:}

Some physical properties for Calendula officinalis plants were used to design the picking machine. The samples were collected randomly from the planted fields. The measurements showed that the plants growing height was ranged from 250 to $450 \mathrm{~mm}$. The main vegetation stem was divided into many brunches to make a small bush. Each branch had many leaves that form the plant canopy. When the plant reaches to a blooming stage, the blooms grow up from the brunches on peduncles. The peduncles reach to a height from $200 \mathrm{~mm}$ to $450 \mathrm{~mm}$. The inflorescences are solitary flower head at the top of the branches. The sepals diameter were ranged from 12 to $45 \mathrm{~mm}$, average orange petals number was 45 petals, the flower hallow stem diameter was ranged from $3 \mathrm{~mm}$ to $7 \mathrm{~mm}$ along the stem and 2-4 $\mathrm{mm}$ near the base of the flower, and the diameter of the flower head was ranged from 50 to100 $\mathrm{mm}$.

\section{(II)Picking machine:}

An experimental picking machine was developed and manufacture to increase maneuverability and capability to pass through Calendula plants in small scale areas. Under Egyptian condition, Calendula planted on row spacing from 600 to $750 \mathrm{~mm}$. The picking crews visit the fields several times in the harvesting season. Three stages of inflorescences were found in the field (flowering buds, open inflorescences, and seeds). The picking always depends on the labor sight. They collect the complete open inflorescences, sent for drying in the open field, then packed. The local farmers do not have cleaning and grading machine as other countries. From that point, manufacturing a machine with wide comb results will increased the strange particles such as leaves and seeds. 


\section{(a)Manual experimental comb:}

The experimental comb was made to determine the ranges of the parameters affected on the Calendula inflorescences picking mechanism to harvest a flower with $20 \mathrm{~mm}$ or less from flower stem, undamaged petals, not to harvest inflorescences seeds, and not harvest un open blooms of inflorescences buds.

A high steel round bars fingers with diameter of $4 \mathrm{~mm}$ were fitted in a Teflon rectangle bar with different lengths and angles to determine the suitable length and angle for cutting the stem with the right length. These fingers were able to decrease and increase their length by moving them inside the Polytetrafluoroethylene (PTFE) Teflon bar, on the hand the angle was changed by changing the angle of Teflon bar fitting in the comb chassis. The experimental comb chassis was manufacture from aluminum $U$ section of $17 \mathrm{~mm}$ height $\times 30 \mathrm{~mm}$ base to form a rectangle inlet orifice with width of $400 \mathrm{~mm}$ and $120 \mathrm{~mm}$ height.

A rear cloth bucket with dimensions of $400 \mathrm{~mm}$ width $\times 400 \mathrm{~mm}$ length $\times 200 \mathrm{~mm}$ height was fixed behind comb to collect the inflorescences. Also, the basket equipped with an upper transparent plastic sheet work as a window for allowing the operator to recognize the fully opened inflorescences. The comb was fitted with steel stick to ease the operator picking work. A brash was fitted along the comb to clean the fingers. The brash was operated by a handy lever located at the left side of the machine. Fig. (1) shows a schematic diagram of the hand held experimental comb parts and its dimensions.

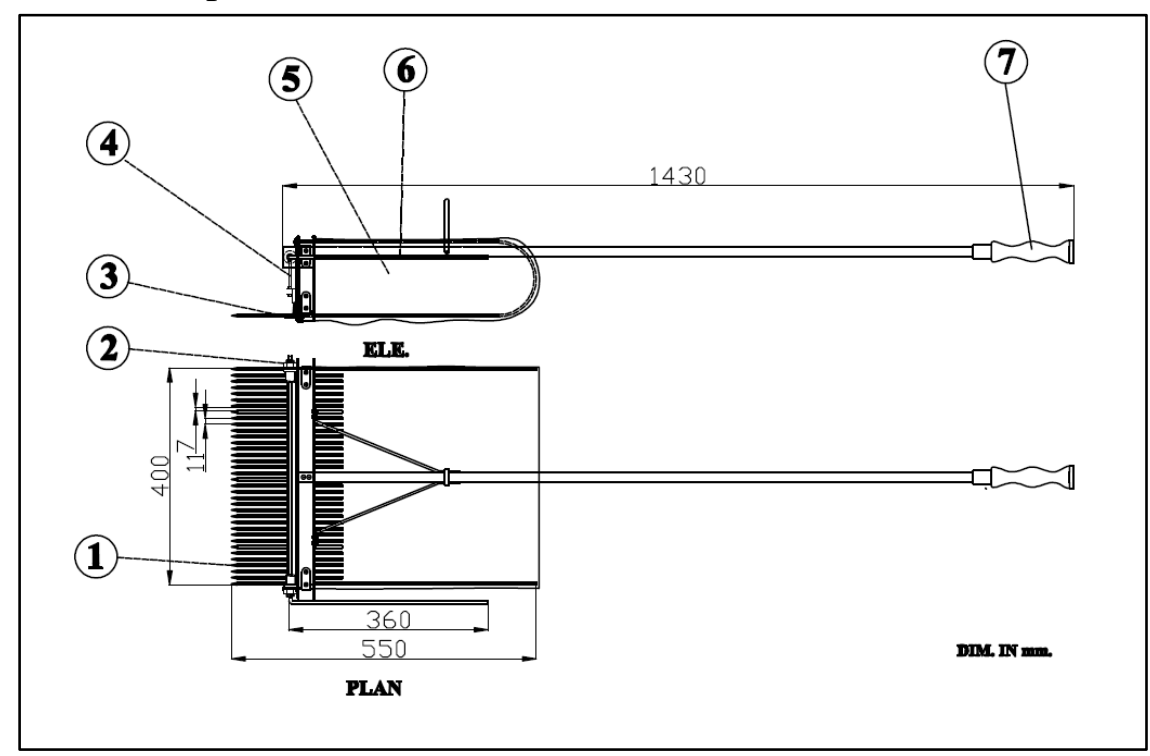

(1) Comb fingers;(2) Cleaning brush bearing ;(3) Fingers fixing bar; (4) Brush arm;

(5) Basket ;(6) Cleaning brush movement arm; (7) Comb handle.

Fig. (1): A schematic diagram of the manual experimental comb

\section{(b) The developed picking machine:}

The developed machine was fabricated from local light materials. It was consisted of a mechanical picking comb and an air vacuum pressure unit. The labor held the picking device by his right hand while the vacuum pressure device was hanged on his back. the labor pass between the chamomile beds, harvest the inflorescences located in his right side by mechanical cut comb, then the vacuum air transferred the picked inflorescences into a basket via a flexible hose. The machine was consisted of two systems:

1-Picking device system. 2-Vacuum pressure inflorescences collector system. 


\section{1-Picking device system:}

\section{Picking comb:}

A number of nineteen high steel round bars fingers with diameter of $4 \mathrm{~mm}$ were fitted in a Teflon rectangle bar and fitted above the cutting mechanism.

\section{Cutting mechanism:}

1. Chassis: The main chassis was made of two aluminum angles with cross section of $(35 \mathrm{~mm}$ length $\times 35 \mathrm{~mm}$ width $\times 4 \mathrm{~mm}$ thickness and length of $305 \mathrm{~mm}$. Both angels were perpendicularly articulated on a fixed aluminum bar with thickness of $3 \mathrm{~mm}$ by bolts and nuts. Two wing bolts were fixed at the end of the chassis to adjust the cutting discs overlapping.

2. Cutting head:

2.1 Cutting discs: Two steel circular saw discs with an outer diameter of $100 \mathrm{~mm}$ and an inner diameter of $20 \mathrm{~mm}$ were used to cut Calendula flowers stems. Each disc inner diameter was fitted to disc holder and locked by plastic nut. A six mm diameter steel rotating shaft was passed through the disc holder and locking by pin. There was a plastic spacer between the plastic locking nut and the metal disc worked as an overload clutch allowed the base of disc holder to slip during clogging. The steel shafts were rotated inside bearing made of special copper alloy that placed in a plastic base housing locked to the chassis by plastic wing nut. Both discs rotated vice versa towards inside position.

2.2 Transmission system: The mechanical transmission was selected to keep a constant power from the electrical motors. The motion was generated by two DC $12 \mathrm{~V}$ motor. Two drive pulleys made of aluminum alloy with diameter of $85 \mathrm{~mm}$ and thickness of $10 \mathrm{~mm}$ were fitted on the motors shafts. The motion was transferred via double cogged V belt to the two steel driven pulleys diameter of $16 \mathrm{~mm}$ coated with nickel and locked to cutting disc shaft. Fig. (2) illustrates the cutting mechanism and its components.

\section{Collecting housing:}

The collecting housing was located underneath the picking comb. The collecting housing was consisted of two curved steel dividers fixed on a steel floor with opening front of $200 \mathrm{~mm}$ and rear end of $100 \mathrm{~mm}$. A steel pipe was located at the rear ends of the two drivers to form a vacuum pressure orifice. The main job of the dividers was steering cut flowers towards the vacuum pressure orifice that located at the end of the picking device. Fig. (3) shows the cutting head and collecting housing. Also, Fig. (4) shows an image of the cutting head and collecting housing.

\section{2-Vacuum pressure Calendula inflorescences collector system:}

The vacuum pressure inflorescence collector was a Cifarelli make knapsack blower BL1200, adjusted to work as an air vacuum pressure, Italian made, equipped with one stroke gasoline engine, $3.6 \mathrm{~kW}$ (5 HP). The blower unit was equipped with a centrifugal fan. A modification was made to the hose to prevent the influences to enter to the blower impeller. The air stream was jetted into a plastic pipe towards a plastic net basket located in the end of the pipe via a venturi. Another plastic pipe was fitted on the main pipe with an angle of $30^{\circ}$ where a flexible collecting vacuum pressure hose was mounted. This mechanism generates a vacuum pressure stream in the collecting flexible hose and smooth transfer for the inflorescences to the basket away from the blower blades. Fig. (5) shows a schematic diagram of the components of the vacuum pressure system of the picking machine. 


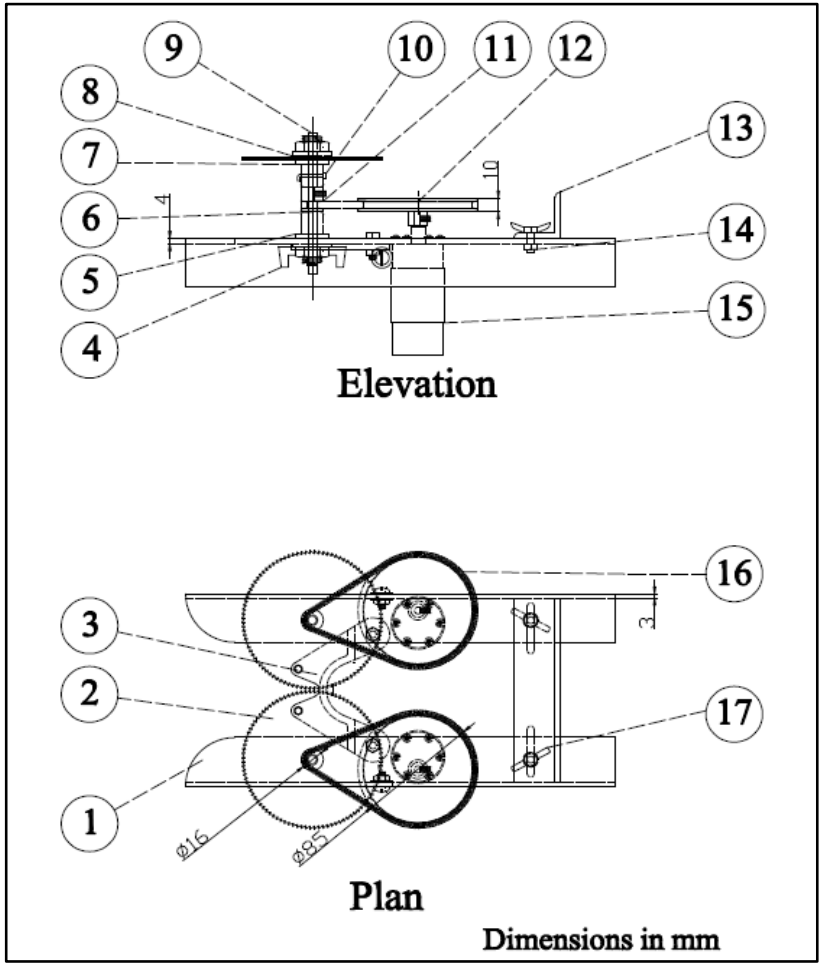

(1) Chassis;(2) Cutting disc;

(3) Articulating plat;(4) Plastic wing nut; (5) Plastic base housing;

(6) Driven pulley; (7) Saw Disc holder;

(8) Overload clutch;

(9) Locking nut; (10) Locking pin; (11)

Journal bearing; (12) Drive pulley; (13)

Adjustment plate;

(14) Discs overlapping wing nut;

(15) DC electrical motor; (16) Double

cogged V belt; (17) Adjustment cutting

discs overlapping.

Fig. (2): The cutting mechanism and its components.

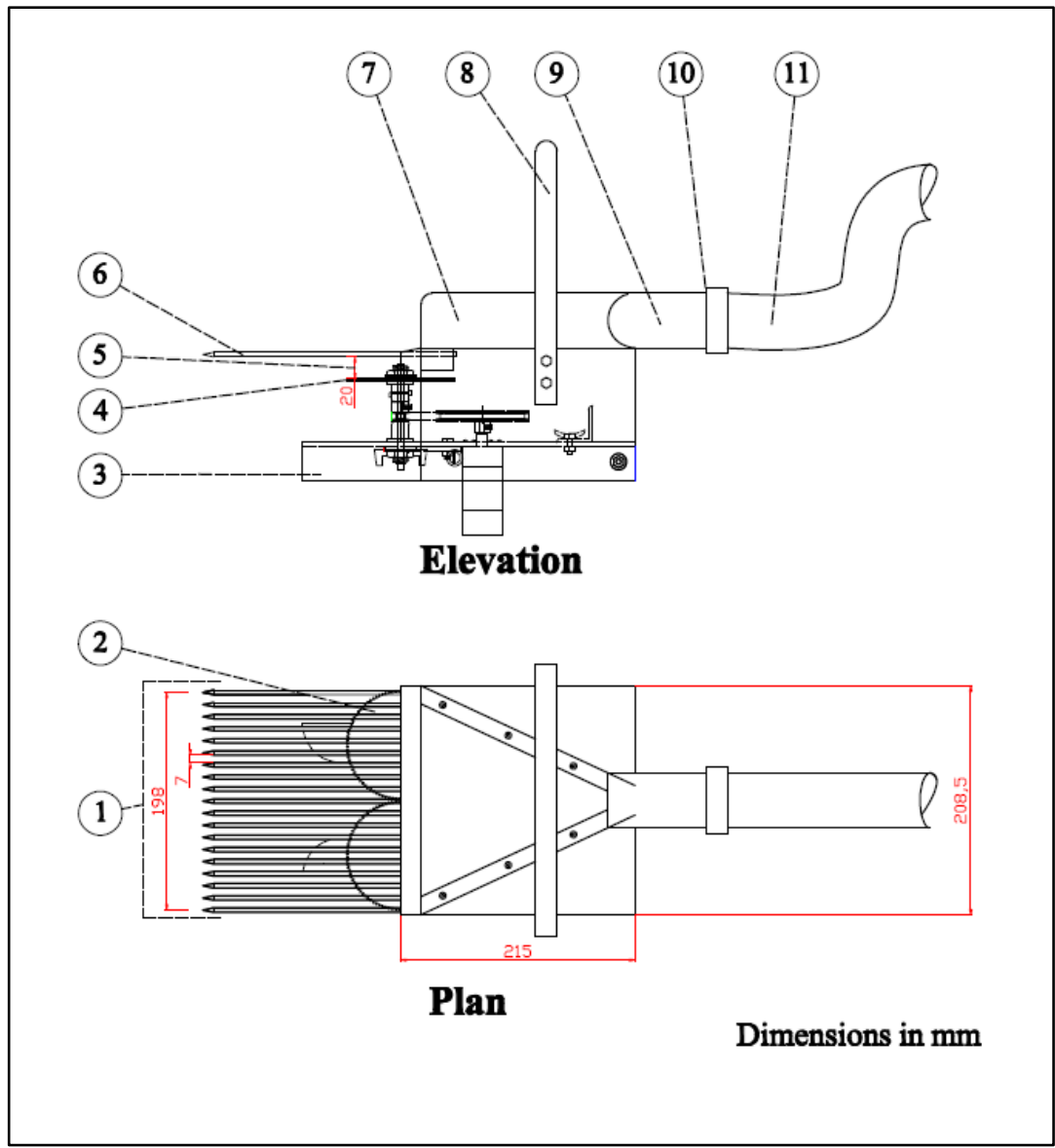

(1) Comb calibration fingers;

(2) Cutting discs;

(3) Aluminum chassis;

(4) Calibration comb chassis;

(5) Flowering stem required cutting clearance;

(6) Calibration fingers;

(7) Collecting dividers;

(8) Operator handle;

(9) Vacuum pressure pipe;

(10) Vacuum pressure pipe strap;

(11) Flexible vacuum pressure hose.

Fig (3): Schematic diagram of the picking head 


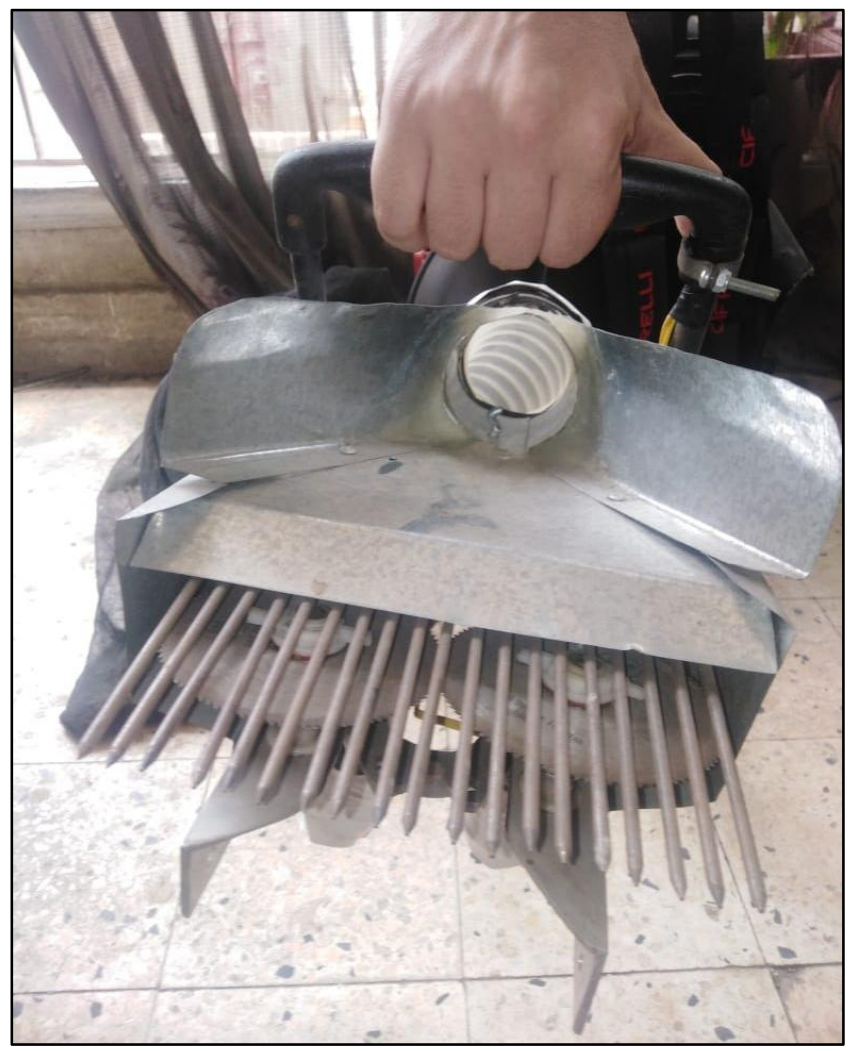

Fig. (4): The cutting head and the collecting housing.

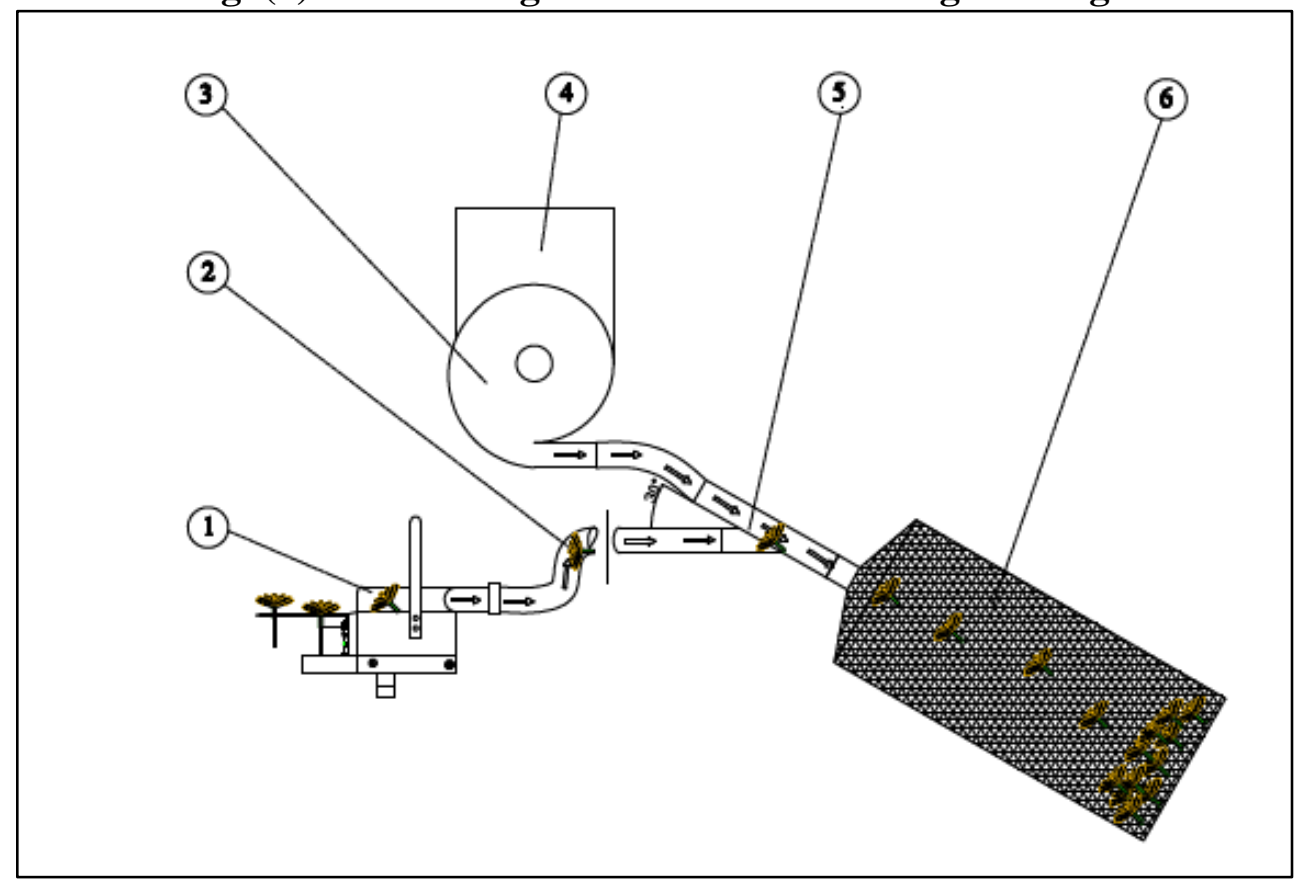

(1) Cutting head ;(2) Flexible vacuum pressure hose; (3) Blower; (4) Engine ;(5) Venturi fitting; (6) Basket.

Fig (5): Schematic diagram of the picking machine

The two systems were worked together synchronously. The procedures as follows: the calibration fingers divided the stems, measured the stem required cutting length, the cutting discs cut the stem on the right length, then the vacuum pressure air stream suck the inflorescences into the basket. Also, Fig. (6) shows an image of the machine during carrying out. 
The machine weight was $12.2 \mathrm{~kg}$ and could be lifted on the operator back. On the other hand, the picking handle was designed with dimensions to reach and cut the flowers without any human strain. The length of flowered plants was measured (250-450mm) to determine the optimum length of the vacuum pressure hose and the operator handle. Also, the operator push button to operate the cutting discs was fitted in a position in the handle easy to push by the thumb finger.

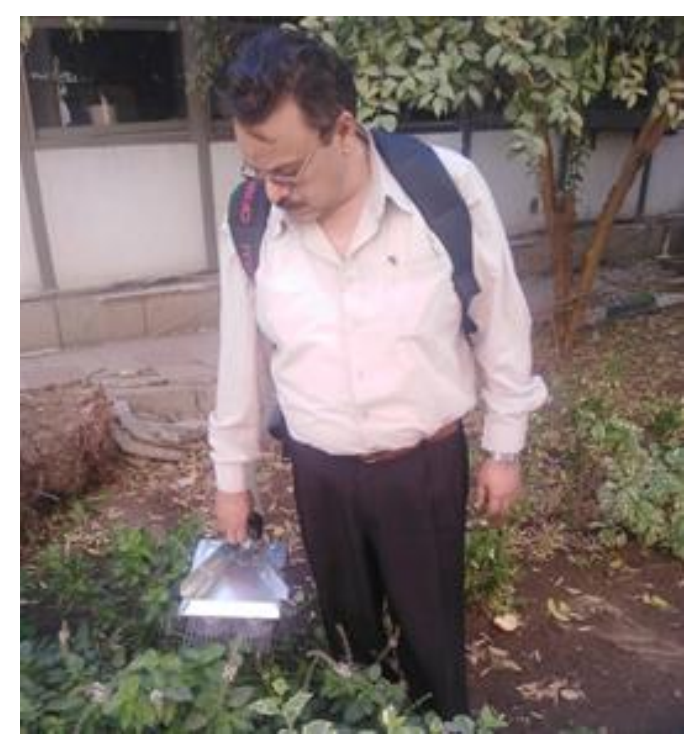

Fig (6): An image of the machine during carrying out

\section{Power determination:}

The method of changing the cutting discs speed mechanically was chosen without using electric resistors or multiple speed motors to measure the exact required power required to cut Calendula inflorescences flowering stems even turning to dry wood matter after making seeds. To calculate the predicted cutting power the following equations were used according to (Andis and Henn, 2014), (Stanford , 1980, 1985, and 1993), and (Thin Kerf ,2016). :-

$$
E=\frac{C \times k \times f_{\operatorname{Max}} \times D}{\text { constant }}
$$

where;

$\boldsymbol{E}=$ Estimated required power, hp;

$C=$ Specific cutting work, joule/ $\mathrm{cm}^{3}$,

$=35$ for softwoods, 40 for dry fir, and 70 for hardwoods; $k=$ Kerf, m;

$k=h+2 \times s$.

$h=$ Thickness of saw disc $=0.09, \mathrm{~cm}$;

$s=$ Side clearance $=0.01, \mathrm{~cm}$.

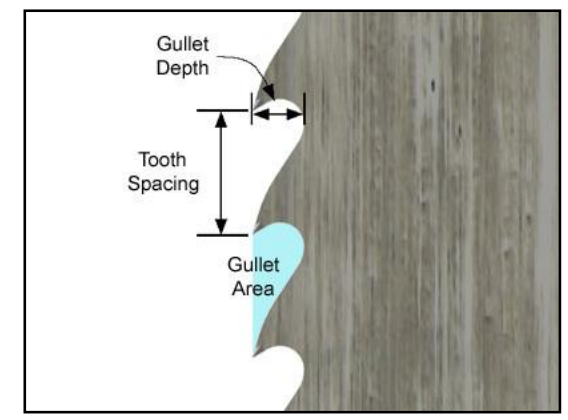

Fig. (7): Disc saw gullet area.

$\boldsymbol{f}_{\boldsymbol{M a x}}=$ Maximum recommended feed speed (m per minute) can be calculated as the following:

$$
\boldsymbol{f}_{\text {Max }}=\frac{\boldsymbol{G F I}_{\operatorname{Max}} \times \boldsymbol{a} \times \boldsymbol{c}}{\boldsymbol{D} \times \boldsymbol{P}}
$$

$\boldsymbol{G F I}_{\text {Max }}=$ Maximum allowable gullet feed index $=0.3$ for circular saws. 
$\mathbf{a}=$ Gullet area measured $\left(\mathrm{cm}^{2}\right)$ as shown in Fig. (7), measured $=0.015 \mathrm{~cm}^{2}$.

$c=$ Blade (or rim) speed can be calculated as: -

$$
c=3.14 \times d \times N \text {. }
$$

$d=$ Circular saw diameter $=10 \mathrm{~cm}$;

$N=$ Circular saw shaft speed $=1594 \mathrm{rpm}$.

$\boldsymbol{D}=$ Depth of cutting $=0.5 \mathrm{~cm}$;

$P=$ Tooth pitch $=3$ pitch $/ \mathrm{cm}$.

$E=0.0024268 \mathrm{hp}=\frac{\mathbf{0 . 0 0 2 4 2 6 8} \times \mathbf{1 0 0 0}}{\mathbf{1 . 3 5 9 6 2}}=1.784958 \mathrm{~W}$

Predicted cutting power $=E \times \mathrm{n}_{d}$

where;

$\mathrm{n}_{\mathrm{d}}=$ number of cutting units $=2$

Predicted cutting power $=3.569917 \mathrm{~W}$

Nominal power $=$ Available power $=\left(\boldsymbol{P}_{\boldsymbol{n}}\right)=\boldsymbol{P}_{\boldsymbol{m}} \times \boldsymbol{n}_{\boldsymbol{m}}$

where;

$\boldsymbol{P}_{\boldsymbol{m}}=$ Electrical motor nominated power, Watt;

$\boldsymbol{n}_{\boldsymbol{m}}=$ Number of used motors.

$\boldsymbol{P}_{\boldsymbol{n}}=2.6 \times 2=5.2 \mathrm{Watt}$

Available power $(5.2 \mathrm{~W})>$ Predicted cutting power $(3.569917 \mathrm{~W})$

Predicted power and actual power:

The experiments were made to cut different Calendula inflorescences cross sections with the picking machine. The current strength was measured. The Actual power requirement $\left(\boldsymbol{P}_{\boldsymbol{a}}\right)$ was calculated from the following equation according to Theraja and Theraja, 2005:

$$
P_{a}=I \times V
$$

where;

$\boldsymbol{P}_{\boldsymbol{a}}=$ Total power requirement for the picker, $W$;

$I$ = Current strength, Amperes;

$V=$ Potential difference, Voltage.

An ampere clamp meter was used to measure current strength when the machine was unloaded. Then, the current strength was measured to calculate the loaded power at different stem cross sections. The consumed cutting power is the result of subtract the loaded power from unloaded power. Fig. (8) clarifies the consumed cutting power at different flowering stems cross sections.

The results indicated that loaded power at the maximum flowering stem cross section $10.75 \mathrm{~mm}^{2}$ was $2.44 \mathrm{~W}$ less than the available power $5.2 \mathrm{~W}$. In case of double flower were cut in the same time (needed $4.87 \mathrm{~W}$ ) the available power still hinger than the needed power.

Measuring instruments:

1- Balance: to weight the mass of the picked inflorescences (accuracy of $1.0 \mathrm{~g}$ ).

2- Vernier caliper: to measure the dimension of the stem length and the stem diameter with accuracy $1 / 20 \mathrm{~mm}$.

3- Stopwatch to record the time consumed during calculation productivity at different experiments. 


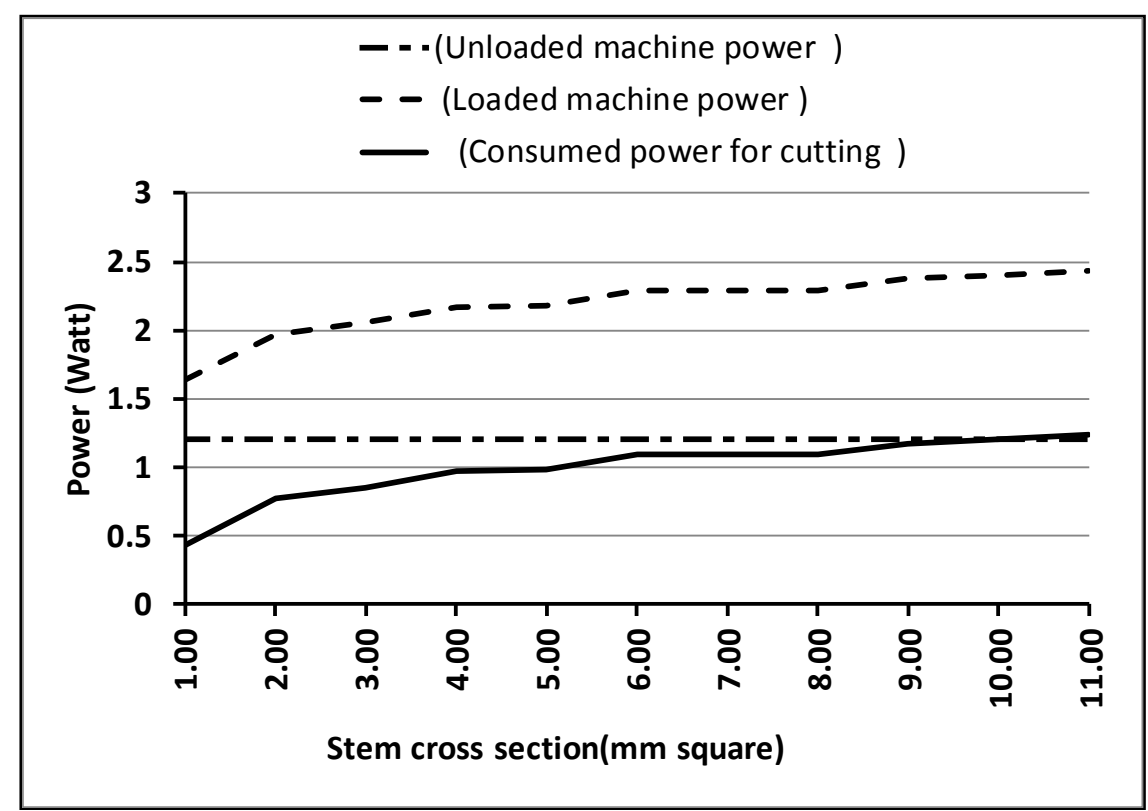

Fig. (8): The consumed cutting power at different stems cross sections.

4- Steel tape: to measure the dimensions of the plants, and both length and width of plots.

5- Tachometer: to measure the rotating speed of the disc saws.

6- Digital force gage: to measure the stem shear force $\left(\boldsymbol{F}^{\boldsymbol{s}}\right)$.Range :( 0-200) N, Sensitivity: $0.1 \mathrm{~N}$.

7- Electrical oven: to measure moisture content in the Calendula inflorescences samples.

8- Image scanner: to image the stem cross section with graded ruler in $\mathrm{mm}$. Then, the images downloaded on AutoCAD program to measure the stem cross section area in $\mathrm{mm}^{2}$.

\section{Testing procedure: -}

The experiments were carried out at a rectangular shape area in Tamiya, Fayom governorate, Egypt. The procedure was taken as weight-based evaluation according to (Katharina and Ehlert, 2014) (Branislav et al. ,2014). The area was divided according to the number of treatments. Each treatment was 5 plots and 3 check spots. Each plot was one meter length $\times 3$ rows with distance between rows $50 \mathrm{~cm}$ (the width of treatment one meter). All the flower within the check spot was collected manually before picking. All the remaining inflorescences on the ground and on the plants at certain height picked manually after picking. Drying the flower samples in an oven at $60 \boldsymbol{C}^{\boldsymbol{o}}$ for 16 hours and weighting them. The inflorescences were weighted at certain moisture content. The classifications of harvested material were determined from samples of $200 \mathrm{~g}$. The inflorescences were sorted and weighted. The productivity was taken as 50 meters $\times$ working width $(0.2 \mathrm{~m})$, working time was measured, weighting the yield after picking each $50 \mathrm{~m}$ plot, and taking samples of moisture content. A condition plot area was collected manually and weighted. Samples were taken and dried to measure their moisture contents.

\section{Test factors: -}

The following treatments were studied to evaluate parameters affecting on the performance of the calendula picking machine:

(1) Cutting disc speed: Five cutting saw shaft speed were used. The cutting disc speed was changing by replacing drive motors and drive pulleys. The motors had built in reduction gears to decrease the motor shaft speed from 300 to 100rpm. 
Table (1): Changing the speed of the cutting disc shafts

\begin{tabular}{|c|c|c|c|c|c|c|}
\hline Motor type & $\begin{array}{c}\text { Motor } \\
\text { speed } \\
(\mathrm{rpm})\end{array}$ & $\begin{array}{c}\text { Drive } \\
\text { pulley } \\
\text { diameter } \\
(\mathrm{mm})\end{array}$ & $\begin{array}{c}\text { Driven } \\
\text { pulley } \\
\text { diameter } \\
(\mathrm{mm})\end{array}$ & $\begin{array}{c}\text { Cutting } \\
\text { shaft } \\
\text { speed(rpm) }\end{array}$ & \multicolumn{2}{|c|}{$\begin{array}{c}\text { Saw cutting } \\
\text { disc linear } \\
\text { speed (m/s) }\end{array}$} \\
\hline SG-555123000-30K & 100 & 85 & 16 & 531 & $\mathrm{~S}_{1}$ & 2.78 \\
\hline SG-555123000-20K & 150 & 85 & 16 & 797 & $\mathrm{~S}_{2}$ & 4.17 \\
\hline SG-555123000-15K & 200 & 85 & 16 & 1063 & $\mathrm{~S}_{3}$ & 5.56 \\
\hline SG-555123000-10K & 300 & 71 & 16 & 1331 & $\mathrm{~S}_{4}$ & 6.97 \\
\hline SG-555123000-10K & 300 & 85 & 16 & 1594 & $\mathrm{~S}_{5}$ & 8.34 \\
\hline
\end{tabular}

(2) Disc cutting blade edge type: Three types of cutting discs with100 mm diameter were used. (Plan discs, 100 teeth saw discs and 50 teeth saw discs).

(3) Calibration fingers length, mm (125 mm, $150 \mathrm{~mm}, 175 \mathrm{~mm}$, and $200 \mathrm{~mm})$. By changing their length inside finger holding bar.

(4) Calibration fingers angle, degree $\left(\mathbf{0}^{\circ}, \mathbf{1 0}^{\circ}\right.$, and $\left.\mathbf{2 0}^{\circ}\right)$. By changing the finger angle of the fingers bar.

Fig. (9) shows the finger angles and finger length adjustments.

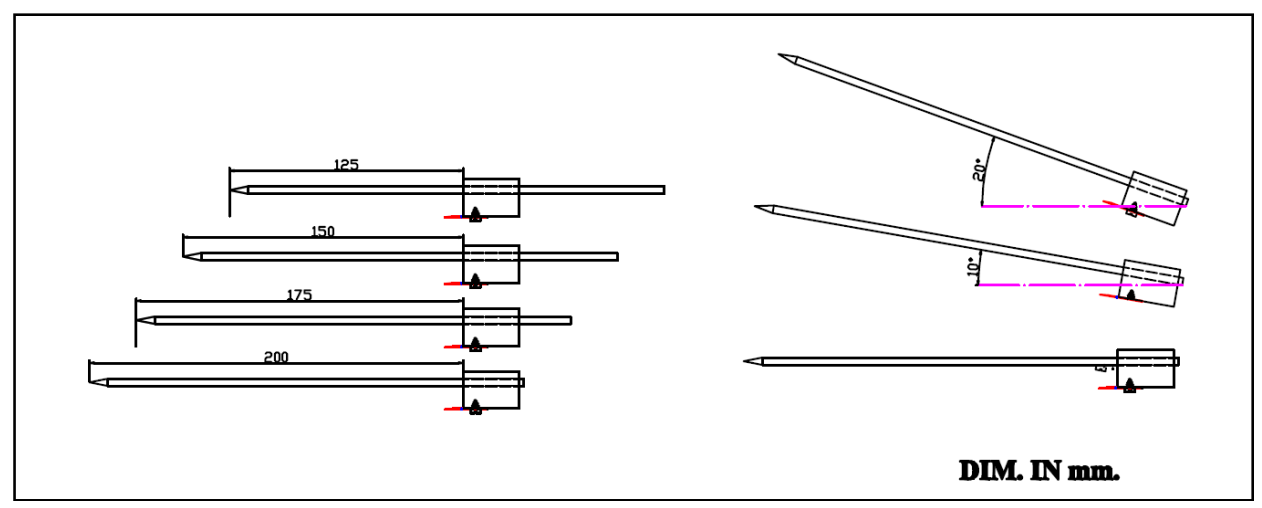

Fig. (9): Finger angle and finger length.

\section{Measurements and calculations: -}

(1) Calendula inflorescences picking evaluation: -

The classification of harvested material and losses in evaluating the performance of flowerpicking machine are divided to: -

(a) Harvested materials: $\left(C_{C}=\right.$ correct cut (stem length $\leq 20 \mathrm{~mm}$ stem $) ; \quad\left(C_{e}=\right.$ Extra cut $($ stem length> $20 \mathrm{~mm}))$; ( $(\mathrm{s}=$ leaves, Calendula seeds and stems $) ;(G W=$ grit and weed $)$.

(b) Remaining flowers $\left(R_{f}\right)$.

(c) Flower picked but not collected) $\left(C_{n}\right)$.

Total flowers picking ratio $T_{P}(\%)=C_{C}(\%)+C_{e}(\%) \ldots \ldots .(7)$

Total picking losses ratio

$T_{l}(\%)=R_{f}(\%)+C_{n}(\%)+l s(\%)+G W(\%)$

(2) Machine productivity. $(\mathrm{kg} / \mathrm{h})$.

(3) The cost analysis was calculated according to Oida, (1997). It performed in two steps. The first step is to calculate the cost of the materials and manufacturing. The second step is to calculate the picking machine operating cost. 
These costs include depreciation $(D)$, annual capital interest taxes $(I)$, housing and insurance $(T H I)$, repair and maintenance $(R)$, power cost $(F)$, and labor cost $(L)$.

$\boldsymbol{T}_{\boldsymbol{c}}=\frac{\{[(\boldsymbol{D})+(\boldsymbol{I})+(\boldsymbol{T H I})]+[(\boldsymbol{R})+(\boldsymbol{F})+(\boldsymbol{L})]\}}{\boldsymbol{n}_{\boldsymbol{a}}}$

where;

$\boldsymbol{T} \boldsymbol{c}=$ Total cost, $\mathrm{LE} / \mathrm{h}$;

$\boldsymbol{n}_{\boldsymbol{a}}=$ Annual working hours $=500 \mathrm{~h}, \mathrm{~h} /$ year.

$T c=\frac{\left\{\left[\left(\frac{P c-S v}{Y}\right)+\left(\frac{(P c+S v)}{2} \times \frac{i}{100}\right)+(0.02 P c)\right]+\left[\left(\frac{P c \times R_{c}}{Y}\right)+\left(P t \times n h \times f_{k W}\right)+F o+\left(N_{l} \times L_{c} \times n_{a}\right)\right]\right\}}{n_{a}} \ldots$

where;

$P c \quad=$ Picking machine manufacturing price, EGP;

$S v \quad=$ Salvage value $=5 \%$ from the Picker manufacturing price EGP;

$i \quad=$ Interest rate $=14 \%$ :

$R c \quad=$ Coefficient of repair and maintenance $=100 \%$;

$Y \quad=$ Machine age $=5$ years;

Pt = Consumed battery charge power, $\mathrm{kW} / \mathrm{h}$;

$n h \quad=$ Number of working hours, h;

$\boldsymbol{f}_{\boldsymbol{k} \boldsymbol{W}}=$ Electrical $\mathrm{kW}$ price $=1 \mathrm{~kW}=1 \mathrm{EGP}$;

$\boldsymbol{N}_{\boldsymbol{I}}=$ Number of labors = (1 labor);

$\boldsymbol{L}_{\boldsymbol{r}} \quad=$ Labor cost $=100 \mathrm{EGP} /$ dav, dav (7 hours), EGP/h:

$\boldsymbol{n}_{\boldsymbol{a}}=$ Annual working hours $=500 \mathrm{~h}, \mathrm{~h} /$ year;

$F o \quad=$ Fuel and oil cost, EGP/h.

\section{RESULTS AND DISCUSSION}

\section{Some mechanical properties of Calendula inflorescences: -}

\section{Flowering stem cross sections shear force $\left(F^{s}\right)$ :}

Flowering stem shear force was measured by using a digital force gage. Also, the cross sections after using the gage were scanned by scanner and calculated by using AutoCAD program. A freshly cut flower stems were used to measure required share force at the right cut position on the stem (20 mm or less). Generally, it realized that the average age of flower since fully opened to the fruiting stage is nearly seven days. In the end of this period, the fiber composition increases inside the stem especially far from flower crown. Therefore, the required share force increased and vice versa. The results indicated that the flowering stem cross section at the right place of cut was differ from plant to another according to the age of plant and agricultural treatments. The results indicated that the maximum required force to share the new opened flower stem was $25.5 \mathrm{~N}$ at cross section of $10.75 \mathrm{~mm}^{2}$. meanwhile, the minimum shear force was $10.90 \mathrm{~N}$ at stem cross section of $3.63 \mathrm{~mm}^{2}$. Fig. (10) manifests the relation between inflorescences stems age and stem shear force. Wherever, by increasing the flowering stem cross-section the shear force increases.

Relation between cutting discs speed and flowers stem right cut at different types of discs:

The experiments were carried out in calendula fields. The spacing between rows was $50 \mathrm{~cm}$ and the spacing between plants was $30 \mathrm{~cm}$. Three types of cutting saw discs were used at five disc speeds of $(2.78,4.17,5.56,6.97$, and $8.34 \mathrm{~m} / \mathrm{s})$ to determine the optimum disc cutting speed and disc type that fitful a higher ratio of right cutting flowering stem $\leq 20 \mathrm{~mm}$. Each treatment was experimented at 5 plots and 3 check spots and the average of five reads was 
taken. Each plot area was one meter $\times$ one meter. The average moisture content in samples for each treatment was $65.75 \%$. All the treatments were made with $\mathbf{0}^{\mathbf{0}}$ finger angle and $125 \mathrm{~mm}$ finger length. The weight of collected flowers was comparing to the weight of the nearest check spot to confirm the representativity of the weight of the treatment.

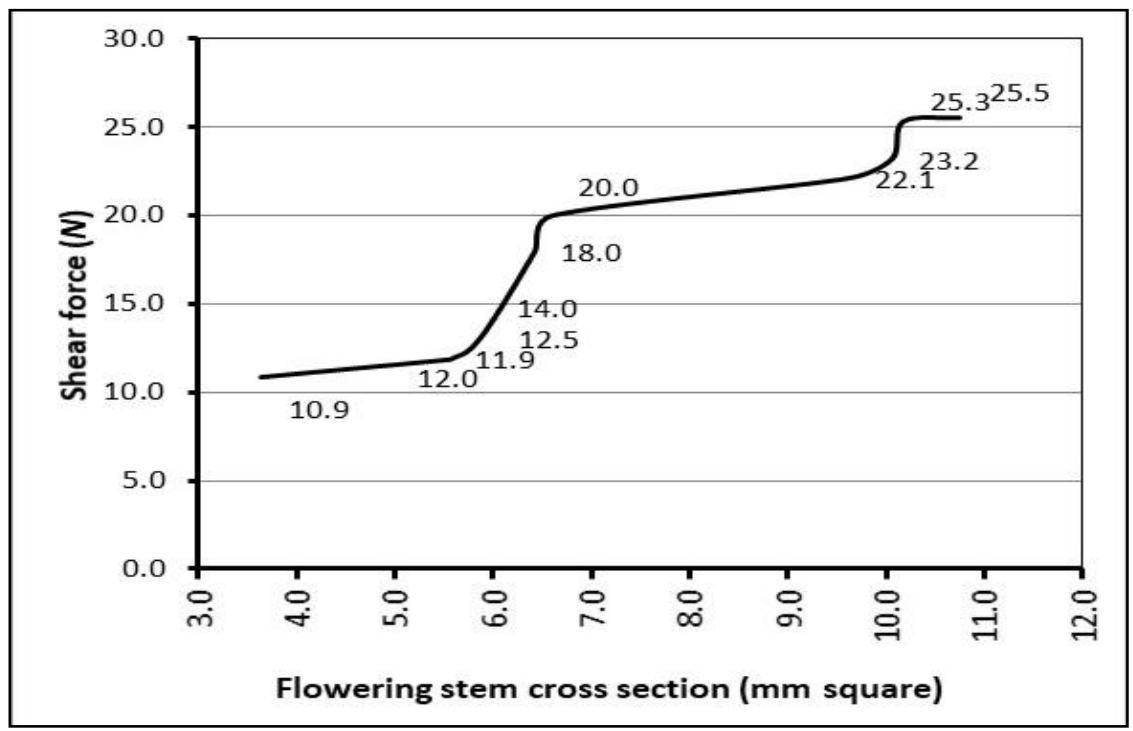

Fig. (10): Relation between flowering stem cross section and shear force $\left(F^{s}\right)$.

The average values of the classification of harvested material are shown in Fig. (11). From Fig. (11), it realized that the maximum average percentage of the correct cut was $91.19 \%$ at disc speed $6.97 \mathrm{~m} / \mathrm{s}$.Meanwhile, the plan cutting discs failed to cut the flowering stem at discs linear speeds 2.78,4.17, and $5.56 \mathrm{~m} / \mathrm{s}$. Plan discs succeed to cut flowering stems at speeds of $6.97 \mathrm{~m} / \mathrm{s}$ and $8.34 \mathrm{~m} / \mathrm{s}$ with low average percentage of correct cut with only $2.00 \%$ and $2.36 \%$ respectively. On the other hand, the average percentage of extra cut at the same speeds was $5.45 \%$ and $5.69 \%$ respectively. The average ratio of the remaining flowers on the plants when using plan discs, 50 teeth discs, and 100 teeth discs was $96.84 \%, 11.75 \%$, and $6.50 \%$ respectively.

Consequently, it realized by increasing the discs linear speed the percentage of correct cutting stems was increased when using the same type of disc saw. By using 50 teeth discs and increasing the discs cutting speed from $\mathrm{S}_{1}$ to $\mathrm{S}_{2}, \mathrm{~S}_{3}, \mathrm{~S}_{4}$, the correct cut is increased by $46.96 \%, 42.15 \%, 31.86 \%$ and the decreased by $20.59 \%$ at $S_{5}$. The relation takes the same trend by using 100 teeth discs with increasing ratio of $56.56 \%, 11.36 \%, 39.88 \%$ the decreased by $8.83 \%$. also, it realized by changing the discs types at the same linear speed the percentage of correct cutting stems was increased. When changing the disc type from 50 to 100 teeth the correct cut was increased by $51.71 \%, 68.73 \%, 52.08 \%, 57.72 \%$, and $61.84 \%$ at $\mathrm{S}_{1}, \mathrm{~S}_{2}, \mathrm{~S}_{3}, \mathrm{~S}_{4}$, and $\mathrm{S}_{5}$ respectively. Meanwhile, the extra cut percentage was decreased by $62.06 \%, 64.49 \%, 17.26 \%, 426.55 \%$, and $260.86 \%$ at the same treatments. The ratio of girt is nearly constant in the same measurements due to the behavior of the plants to bloom away from to vegetation area. The average percentages of "leaves and Calendula seeds, stems" and "girts and weeds" at all treatments were nearly the same due the morphology of the plant that blooms away from vegetation. Also, the machine work away from the vegetation canopy.

Fig. (12) shows the relation between cutting discs speed and total picking ratios at different types of discs. 


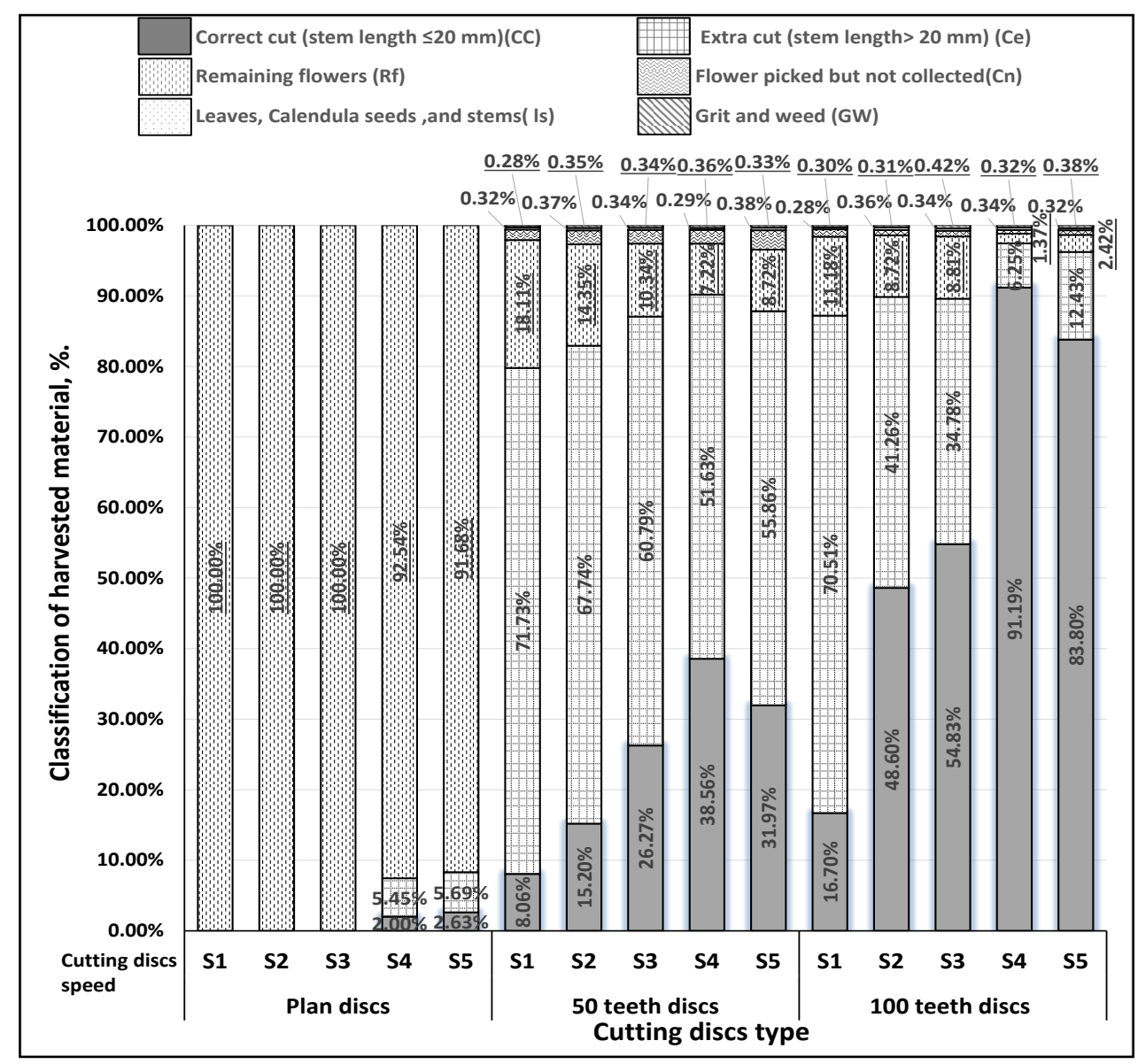

Fig. (11): Relation between cutting discs speed and classifications of harvested materials at

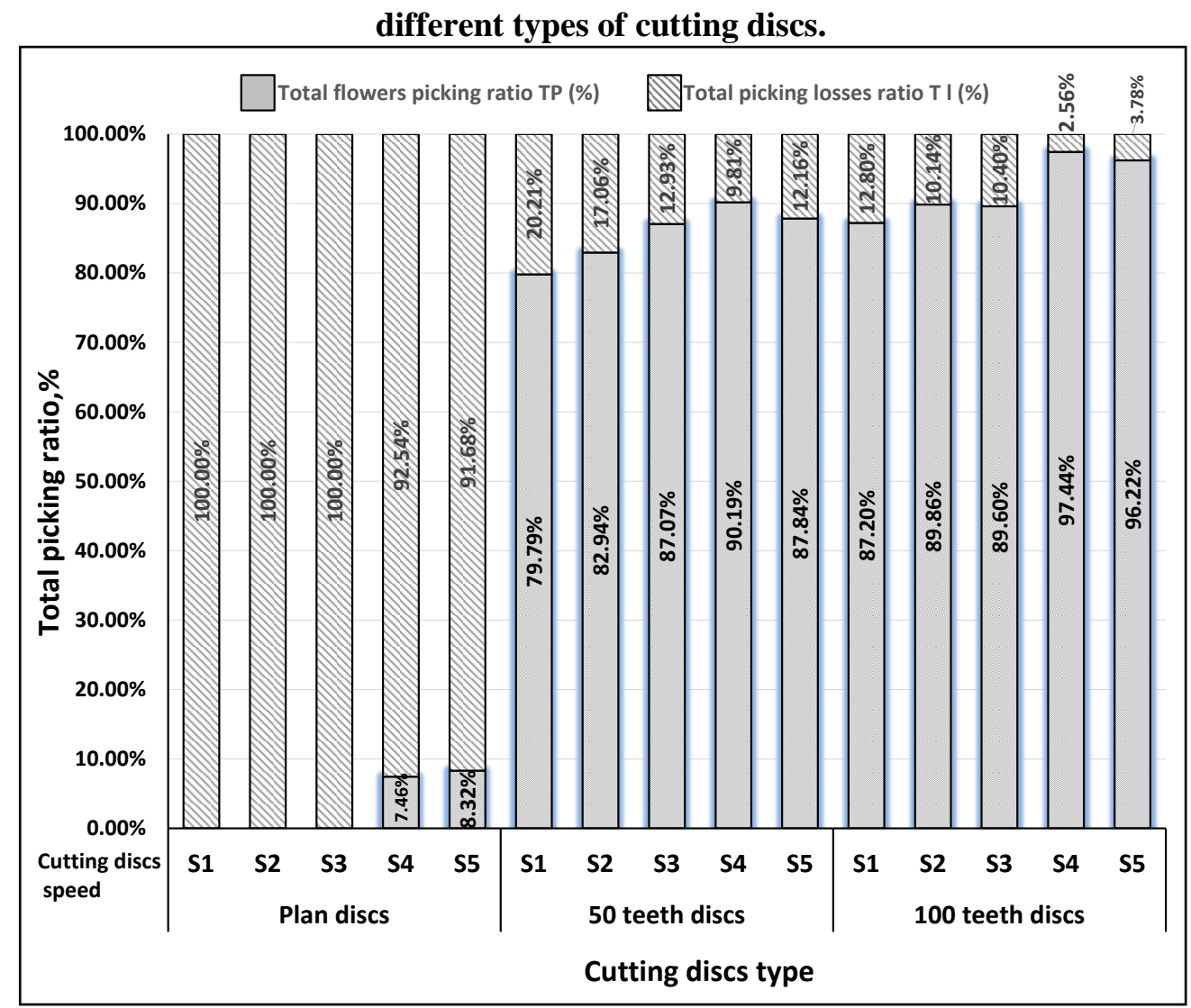

Fig. (12): Relation between cutting discs speed and total picking ratio at different types of discs. 
From Fig. (12), at 50 and 100 teeth results. it was realized that the maximum value of total picking ratio was $97.44 \%$ at 100 teeth disc and S4 linear speed the total picking ratio is increased by increasing the disc linear speed. When using 50 teeth disc, by increasing the linear speed from $S_{1}$ to $S_{2}, S_{3}, S_{4}, S_{5}$ the total picking ratio was increased by $3.95 \%, 9.11 \%, 13.3 \%, 10.8 \%$ respectively. Also, when using 100 teeth disc, by increasing the linear speed from $S_{1}$ to $S_{2}, S_{3}, S_{4}, S_{5}$ the total picking ratio was increased by $3.33 \%, 2.75 \%, 11.74 \%, 10.34 \%$ respectively. The different between the ratio of total picking between $\mathrm{S}_{4}$ and $\mathrm{S}_{5}$ when using 100 teeth disc was only $1.39 \%$ due to the weight variation of flowers per square meter in some plots. This means the increasing of number of disc teeth and the disc linear speed is directly increasing the total percentage of correct cut ratio and the total picking ratio.

From Fig. (11) and Fig. (12), The results indicated that the optimum disc linear speed is 6.97 $\mathrm{m} / \mathrm{s}$ with 100 teeth discs type that give percentage of correct stem cut $91.19 \%, 6.25 \%$ extra stem cut, 1.37 remaining flowers, $0.53 \%$ flower cut but not collected, $0.34 \%$ leaves \& stems , $0.32 \%$ girt and weeds. This percentage gave a total picking ratio $97.44 \%$ and total losses of $3.78 \%$.

$\underline{\text { Relation between calibration fingers length and classifications of harvested material at }}$ different calibration fingers angels:

The same procedures were taken at the optimum disc linear speed $6.97 \mathrm{~m} / \mathrm{s}$ and 100 teeth discs at finger length of $125 \mathrm{~mm}, 150 \mathrm{~mm}, 175 \mathrm{~mm}$, and $200 \mathrm{~mm}$ at three finger angles.

The average values of the classification of harvested material are shown in Fig. (13). From Fig. (13), Generally, it was realized that the correct cut percentage was decreased by increasing the finger angel from $10^{\circ}$ to $20^{\circ}$ but increased when increasing the finger angle from $0^{\circ}$ to $10^{\circ}$. Also, it realized that the maximum percentage of average correct cut was $93.31 \%$ at finger length $150 \mathrm{~mm}$ and finger angle $10^{\circ}$. Meanwhile, the minimum percentage of average correct cut was $84.14 \%$ at finger length $200 \mathrm{~mm}$ and finger angle $20^{\circ}$.

The result indicted that the finger length has a direct effect on the correct cut percentage. At finger angle of $0^{\circ}$, by increasing the finger length from $125 \mathrm{~mm}$ to $150 \mathrm{~mm}, 175 \mathrm{~mm}$ and $200 \mathrm{~mm}$ the correct cut percentage was increased by $0.30 \%$ then decreased by $-0.08 \%$ and $1.22 \%$ respectively. At finger angle of $10^{\circ}$, by increasing the finger length from $125 \mathrm{~mm}$ to $150 \mathrm{~mm}, 175 \mathrm{~mm}$ and $200 \mathrm{~mm}$ the correct cut percentage was increased by $0.77 \%$ then decreased by $-1.35 \%$ and $3.14 \%$ respectively. At finger angle of $20^{\circ}$, by increasing the finger length from $125 \mathrm{~mm}$ to $150 \mathrm{~mm}, 175 \mathrm{~mm}$ and $200 \mathrm{~mm}$ the correct cut percentage was increased by $0.01 \%$ then decreased by $2.06 \%$ and $2.65 \%$ respectively.

By increasing the finger length from $125 \mathrm{~mm}$ to $150 \mathrm{~mm}, 175 \mathrm{~mm}, 200 \mathrm{~mm}$, the extra stem average percentage were decreased by $\left(10.69 \%, 14.51 \%, 12.87 \%\right.$ at finger angle $0^{\circ}$ ), $\left(16.90 \%, 10.91 \%, 6.97 \%\right.$ at finger angle $\left.10^{\circ}\right)$ and $\left(2.31 \%, 14.38 \%, 22.61 \%\right.$ at finger angle $\left.20^{\circ}\right)$ respectively.

The average percentages of "leaves and Calendula seeds, stems" and "girts and weeds" at all treatments were nearly the same due the morphology of the plant that blooms away from vegetation. Also, the machine work away from the vegetation canopy.

The average values of the picking ratio at different calibration fingers angels are shown in Fig. (14). 


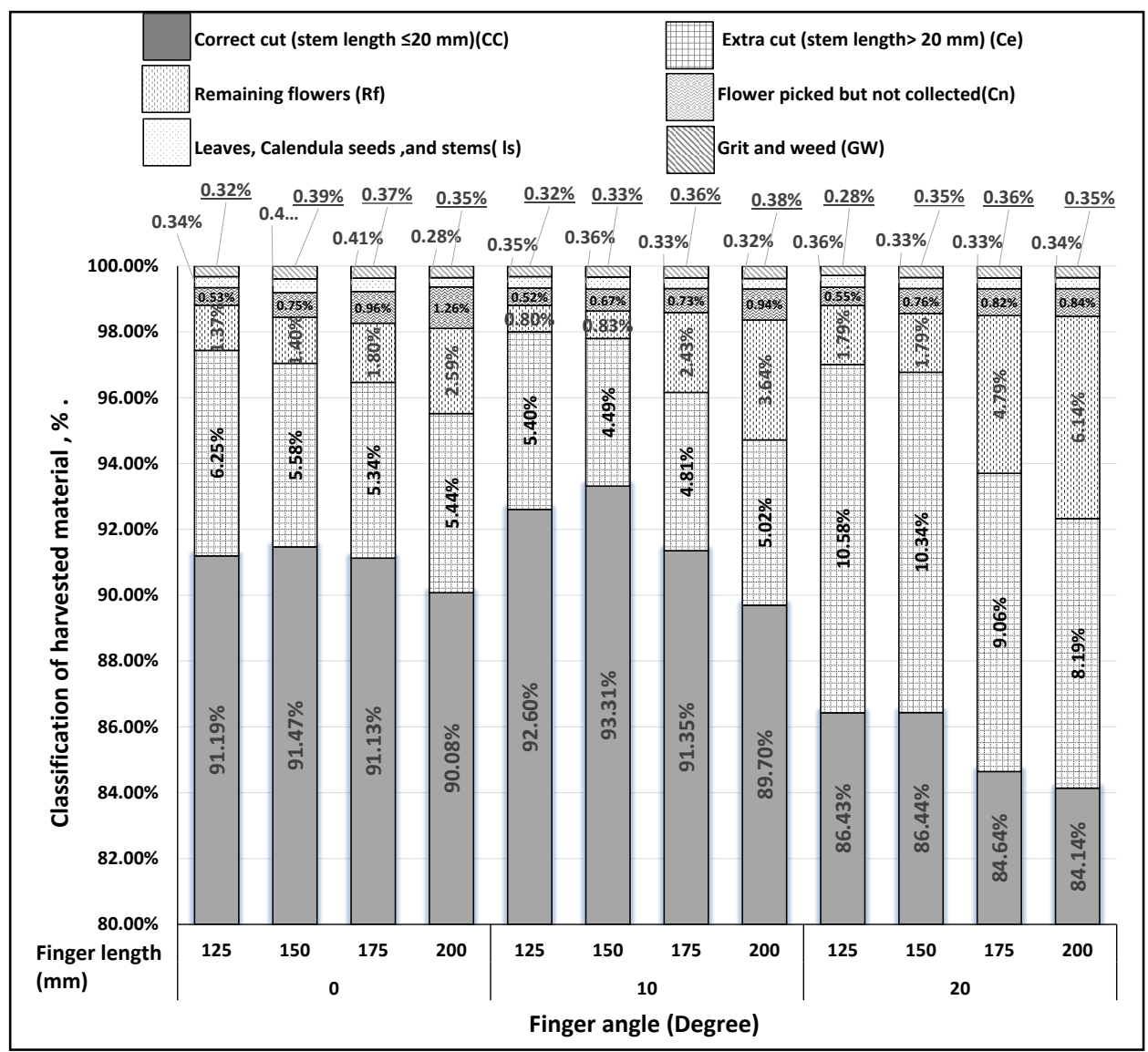

Fig. (13): Relation between calibration fingers length and classifications of harvested material at different calibration fingers angels.

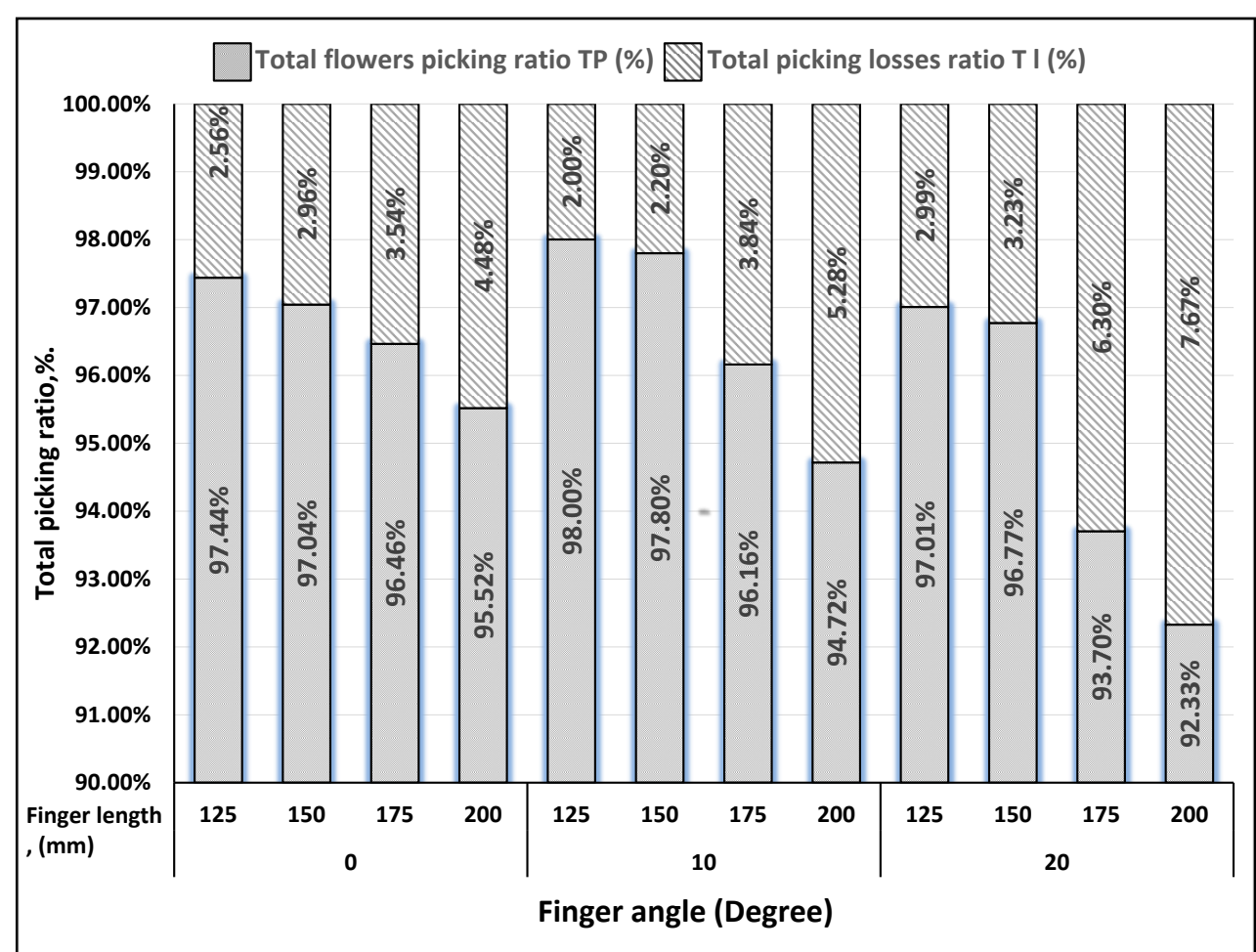

Fig. (14): Relation between calibration fingers length and picking ratio at different calibration fingers angels. 
From Fig. (14), it realized that the maximum percentage of total picking ratio was $98.00 \%$ at finger length of $125 \mathrm{~mm}$ and finger angle $10^{\circ}$. Then, it was followed by total picking ratio of $97.8 \%$ and total losses of $2.2 \%$ at finger length of $150 \mathrm{~mm}$ and the same finger angle. On the other hand, the minimum percentage of total picking ratio was $92.33 \%$ at finger length of $200 \mathrm{~mm}$ and finger angle $20^{\circ}$.

At finger angle $0^{\circ}$, by increasing the finger length from $125 \mathrm{~mm}$ to $150 \mathrm{~mm}, 175 \mathrm{~mm}, 200 \mathrm{~mm}$ the picking ratio only increased by $0.58 \%$ then decreased by $1.00 \%$ and $1.97 \%$ respectively. Also, at finger angle $10^{\circ}$, it decreased by $1.01 \%, 1.88 \%$ and $3.35 \%$ respectively and takes the same trend at $20^{\circ}$ be decreased by $0.24 \%, 3.41 \%, 4.83 \%$ respectively. This means that finger length has a direct effect on the total picking ratio.

Comparing the total picking ratio with the same finger lengths at different finger angles. At finger length of $125 \mathrm{~mm}$, when changing the finger angle from $\left(0^{\circ}\right.$ to $\left.10^{\circ}\right)$ then from $\left(0^{\circ}\right.$ to $20^{\circ}$ ) it was realized that the total picking ratio was increased by $0.57 \%$ then decreased by $0.44 \%$. Also, it takes the same trend with fingers length $150 \mathrm{~mm}$. At finger lengths $(175 \mathrm{~mm}$, and $200 \mathrm{~mm})$, it decreased by $(0.31 \%$, and $2.95 \%)$ and $(0.85 \%$, and $3.46 \%)$ respectively. This means, the finger angle has a low effect on the total picking ratio.

The results indicated that the optimum adjustments were at disc linear speed is $6.97 \mathrm{~m} / \mathrm{s}$ with 100 teeth discs type, at finger length $150 \mathrm{~mm}$ and finger angle $10^{\circ}$ that give average percentage of correct stem cut $93.31 \%, 4.49 \%$ extra stem cut, $0.83 \%$ remaining flowers, $0.67 \%$ flower cut but not collected, $0.36 \%$ leaves \& stems , $0.33 \%$ girt and weeds. This percentage gave a total picking ratio $97.80 \%$ and total losses of $2.20 \%$.

A step wise regression was made by using SPSS 17 Statistics program to confirm the parameters effect on the correct cut percentage $\left(\mathrm{C}_{\mathrm{C}}\right)$. The stepwise procedure added a variable in each step. The process stopped when there were no variables it could add or remove from the model. The final row displays the model 3 that the procedure produced. The three independent variables in our model are disc type, disc speed and finger length. This model has an R-squared of $90.6 \%$ and the highest adjusted R-squared as shown in Table (2).

$$
\mathrm{C}_{\mathrm{C}}=-0.718+0.007 \mathrm{X}_{1}+0.073 \mathrm{X}_{2}+0.002 \mathrm{X}_{4}
$$

where;

$\mathrm{X}_{1}=$ Number of disc teeth, $\mathrm{X}_{2}=$ disc speed, $\mathrm{X}_{4}=$ calibration fingers length, $\mathrm{R}=$ regression, $\mathrm{R}^{2}=$ coefficient of determination, and S.E. $=$ standard error.

The program was neglected $\mathrm{X}_{3}=$ calibration fingers angle.

\section{Machine productivity:}

The machine productivity was taken as 50 meters length of planted calendula $\times$ working width $(0.2 \mathrm{~m})$, consumed time was taken, weighting the yield after picking each $50 \mathrm{~m}$ plot, and taking samples to lab to make moisture content. The average moisture content for freshly cut flowers was $65.75 \%$. A condition plot area was collected manually and weighted to compare 
the productivity. The machine productivity at the optimum parameters was $0.0576 \mathrm{Mg} / \mathrm{h}$ from freshly cut flower gave $0.01973 \mathrm{Mg} / \mathrm{h}$ dried flowers.

Table (2): Step wise regression results for the parameters effects on the stem correct cut.

\begin{tabular}{|c|c|c|c|c|c|c|}
\hline & \multicolumn{2}{|l|}{ Model 1} & \multicolumn{2}{|l|}{ Model 2} & \multicolumn{2}{|l|}{ Model 3} \\
\hline & Coefficient & $\begin{array}{l}\mathrm{P} \\
\text { value }\end{array}$ & Coefficient & $\begin{array}{l}\mathrm{P} \\
\text { value }\end{array}$ & Coefficient & $\begin{array}{l}\mathrm{P} \\
\text { value }\end{array}$ \\
\hline Constant & -0.052 & 0.496 & -0.487 & 0.000 & -0.718 & 0.000 \\
\hline $\mathrm{X}_{1}$ & 0.008 & 0.000 & 0.007 & 0.000 & 0.007 & 0.000 \\
\hline $\mathrm{X}_{2}$ & ------- & ------- & 0.081 & 0.000 & 0.073 & 0.000 \\
\hline $\mathrm{X}_{4}$ & ------- & ------- & -------- & ------- & 0.002 & 0.045 \\
\hline $\mathrm{R}$ & \multicolumn{2}{|l|}{0.877} & \multicolumn{2}{|l|}{0.942} & \multicolumn{2}{|l|}{0.952} \\
\hline $\mathrm{C}_{\mathrm{C}} \mathrm{R}^{2}$ & \multicolumn{2}{|l|}{0.770} & \multicolumn{2}{|l|}{0.887} & \multicolumn{2}{|l|}{0.906} \\
\hline Adjusted $\mathrm{R}^{2}$ & \multicolumn{2}{|l|}{0.760} & \multicolumn{2}{|l|}{0.877} & \multicolumn{2}{|l|}{0.894} \\
\hline $\begin{array}{l}\text { Std. Error of the } \\
\text { Estimate }\end{array}$ & \multicolumn{2}{|c|}{0.187385799} & \multicolumn{2}{|c|}{0.134106512} & \multicolumn{2}{|c|}{0.124899144} \\
\hline
\end{tabular}

\section{Cost analysis and economical evaluation:}

The calculation of the operating costs included fixed and variable costs were made for Calendula picking machine. The total operating costs for Calendula picking machine 33.07 EGP /h. The labor could harvest $0.025-0.030 \mathrm{Mg} /$ day (day seven hours) of fresh inflorescences nearly $0.00147 \mathrm{Mg} / \mathrm{h}$ of dry inflorescences. Meanwhile, the machine productivity was $0.01973 \mathrm{Mg} / \mathrm{h}$ of dry inflorescences at the optimum adjusted effective parameters. The labor cost was 14.29 EGP/h while, the machine cost was $33.07 \mathrm{EGP} / \mathrm{h}$. This mean, the cost of one Megagram of dry crop harvested by the machine was $1676.51 \mathrm{EGP} / \mathrm{Mg}$ against $7785.89 \mathrm{EGP} / \mathrm{Mg}$ of the crop collected by hand.

-Economic studies:

The total fabrication cost of the picking machine was 10000 EGP include the modification with year 2019 prices level. The total operating costs was 33.07 EGP/h. The picking machine indicated NPV of 2747.24 EGP at $14 \%$ interest rate. The picking machine payback period was about 1.28 year with rental price $60 \mathrm{EGP} / \mathrm{h}$.

\section{SUMMARY AND CONCLUSION}

The obtained results can be summarized as follows:

1-The machine success to harvest Calendula inflorescences in small areas conditions owned by small farmers at the at disc linear speed is $6.97 \mathrm{~m} / \mathrm{s}$ with 100 teeth discs type, at finger length $150 \mathrm{~mm}$ and finger angle $10^{\circ}$ that give average percentage of correct stem cut $93.31 \%$, $4.49 \%$ extra stem cut, $0.83 \%$ remaining flowers, $0.67 \%$ flower cut but not collected, $0.36 \%$ leaves \& stems, $0.33 \%$ girt and weeds. This percentage gave a total picking ratio $97.80 \%$ and total losses of $2.20 \%$. 
2- The performance of the machine directly affected by the calibration angle of $\mathbf{1 0}^{\mathbf{0}}$ but the machine performance decreased at calibration angle of $\mathbf{2 0}^{\circ}$.

3 - The performance of the machine directly affected by the calibration finger length $125 \mathrm{~mm}$ and $150 \mathrm{~mm}$, but the machine performance decreased with calibration finger $175 \mathrm{~mm}$ and $200 \mathrm{~mm}$ according to the lost time taken to measure the stem correct length.

4- The machine succeeded to decrease the picking Calendula costs. The cost of one Megagram of dry crop harvested by the machine was 1676.51EGP/Mg against 7785.89EGP/Mg of the crop collected by hand.

\section{The following conclusions and recommendations can be drawn:}

1-The picking machine can be manufactured locally with cheap price for small farm holder.

2-Providing such a picking machine is surly decrease the Calendula picking costs (Only 1676.51EGP/Mg against 7785.89EGP/Mg of the crop collected by hand) and encourage the farmers to grow Calendula.

3-Using the machine is surly increase the market value of the mechanically picked inflorescences due to the machine keeps them without damage and away from labor hand.

4- Using mechanical harvesting will increasing the numbers of picking crew visits to the fields in a short time interval, this procedure increases the chance to have a product free of Calendula seeds and increasing the quality of picked flowers.

5-Trying to use the picking machine with different kinds of medicinal and aromatic crops.

\section{ACKNOWLEDGMENT}

The authors sent their sincere regards to the Academy of Scientific Research and Technology (ASRT) for its support in this research under umbrella of the project of "Promoting the Cultivation, Processing, and Marketing of Medicinal and Aromatic Plants".

\section{REFERENCES}

Andis, Ā. and T. Henn (2014). Relation between mechanical and electric power at longitudinal sawing. Forestry and wood processing. Research for rural development. Volume (2).

Brabandt ,H. and D. Ehlert (2011). Chamomile harvesters: A review. Ind Crop Prod 34: 818-824.

Branislav, V.; D. Adamovic ; M. Martinov ; M.Viskovic ; M. Golub1 and S. Bojic (2014). Mechanized harvesting and primary processing of Calendula officinalis L. inflorescences. Spanish Journal of Agricultural Research 12(2): 329-337.

Dachler,M. and H. Pelzmann (1999). Arznei- und Gewürzpflanzen(Anbau, Ernte, Aufbereitung). Agrarferlag, Wien, Austria: 352.

Herold, M.; F. Pank ; E. Menzel,; H. Kaltofen,; E. Loogk, and H. Rust (1989). Verfahrenstechnische Entwicklungen zum Anbau von Chamomila recutia L. 
(Rauschert) und Calendula officinalis L. für die Gewinnung von Blütendrogen. Drogenreport 2: 43-62.

Hecht, H.; T. Mohr, and S. Lambrecht, (1992). Mechanisierung der Blütendrogenemte. Landtechnik 47: 276-280.

Hendawy, S.; M. Abd Elwahab and W. Abel Moez (2013). Calendula. Upgrading the medicinal and aromatic plants value chain- Access to export. Guidelines for the production and handling medicinal and aromatic plants. EMAP. second edition:1-12.

Kisgeci, J. and D. Adamovic (1994). Gajenje lekovitog bilja. Nolit, Beograd, Srbija: 213.

Khalid, K.A. and JA. T. da Silva (2012). Biology of Calendula officinalis Linn.: Focus on pharmacology, biological activities and agronomic practices. Med Aromat Plant Sci Biotechnol 6(1): 12-27.

Katharina,B. and D. Ehlert (2014). Methods for evaluation of picking performance of Chamomile (Matricaria recutita L.) harvesters. Part II: Development of new methods Journal of Applied Research on Medicinal and Aromatic Plants.

Mohr, T. (2002). Untersuchung und Weiterentwicklung einer Erntemaschine für Heilpflanzen. Z Arznei- Gewürzpflanzen7 (Sonderausgabe): 96-202.

Martinov, M. and D. Adamovic (2002). Mechanized harvesting of pyrethrum (Pyrethrum cinerariaefolium Trev.)- First Testing. Med Plant Rep 9: 23-27.

Martinov, M. and M. Konstantinovic (2007). Harvesting. In: Medicinal and aromatic crops. Harvesting, drying, and processing (Öztekin S, Martinov M, eds.). The Haworth Press Inc., NY, (USA): 56-84.

MOALR "Ministry of agriculture and Land Reclamation" (2019). Bulletin of the agricultural statistics. Part (1) Winter Crops, 2017\} 2 0 1 8 .

Oida , A. (1997). Using personal computer for agricultural machinery management. Kyoto University. Japan. JICA publishing.

Stanford, J. L. (1980). How to calculate required horse power for circular saw. Issue 10 of Technical report (United States. State and Private Forestry. Forest Products Utilization).

Stanford, J. L. (1985). Balanced saw performance. Issue 12 of Technical report (United States. State and Private Forestry. Forest Products Utilization).

Stanford, J. L. (1993). Circular sawmill and their effective operation. USDA Forest Service State and Private Forestry.

Theraja, B.L. and A.K. Theraja, (2005). A text book for electrical technology. S.chand \&company limited. Vol. 1. 
Thin Kerf (2016). Alignment procedures and instruments for edgers. Precision alignment tools. Publication (2).

Veselinov, B.; D. Adamovic, and M. Martinov (2008). Investigation of possibility of mechanized marigold inflorescences harvesting. Bull Hops Sorghum Med Plant 81: 22-33.

Willoughby, R.A.; J.B. Solie ; R.W. Whitney; N.O. Maness and M.D. Buser (2000). A mechanical harvester for marigold inflorescences. Proc ASAE Annul Intonational Meeting, Milwaukee, WI, USA: 1-14.

Zimmer, S. and J. Müller (2004). Harvesting technology of medicinal and aromatic plants. Gülzow technical discussions: 22-100. 


\section{تطوير آلة لقطف زهور الكلانديولا لتناسب صغار المزارعين}

د/ طارق حسين محمد '، د/ سحر السيد موسي' و د/طارق عثمان حماد`

'باحث أول بمعهد بحوث الهندسة الزراعية ـ مركز البحوث الزر اعية بالدقي ـ الجيزة ـ مصر.

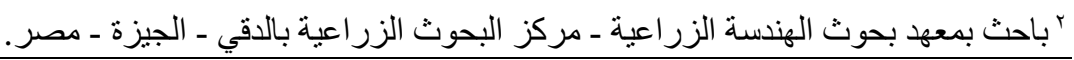

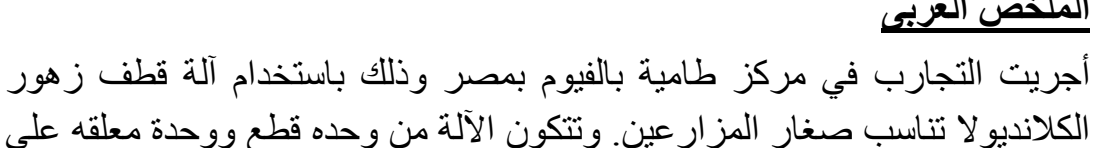

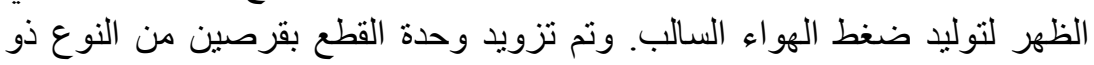

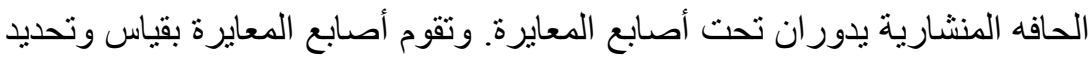

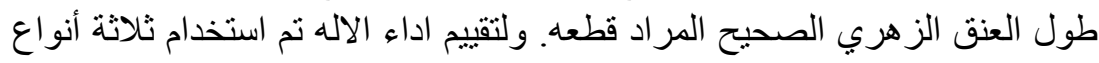

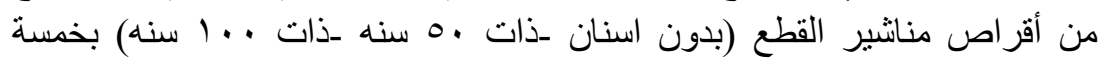

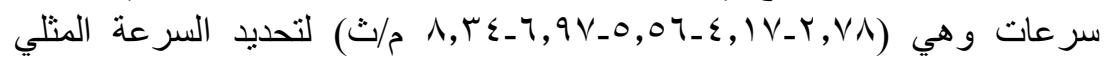

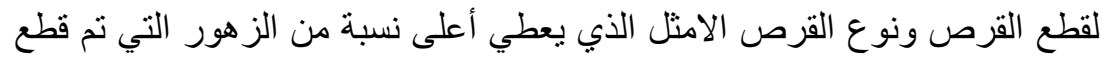

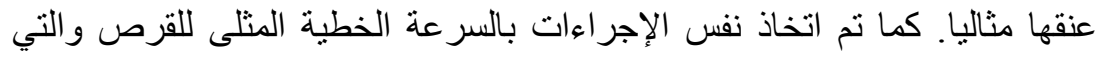

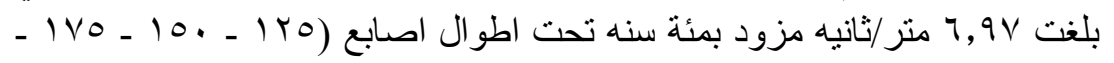

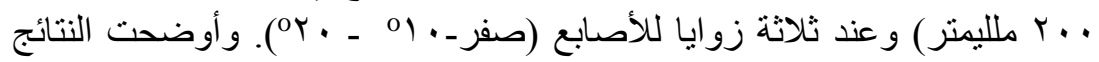

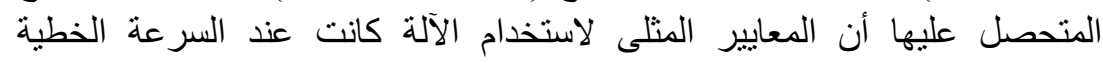

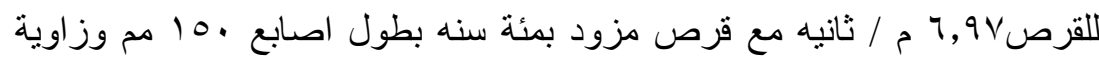

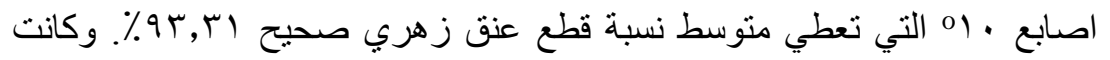

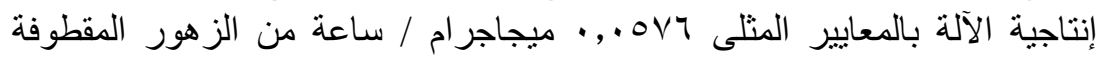

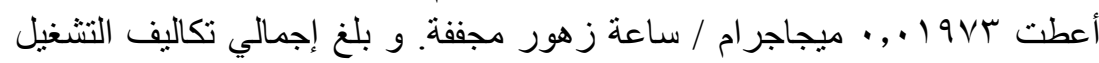

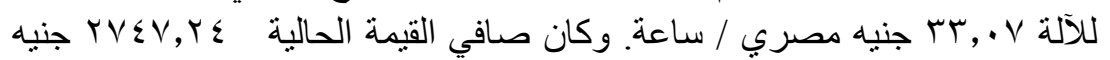

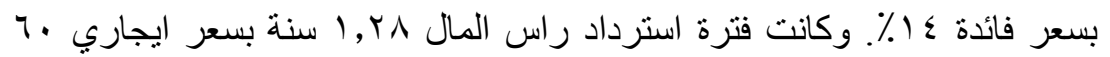

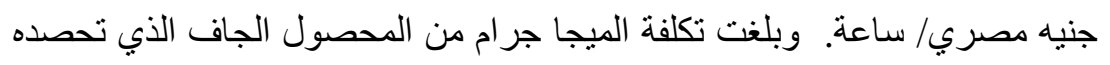

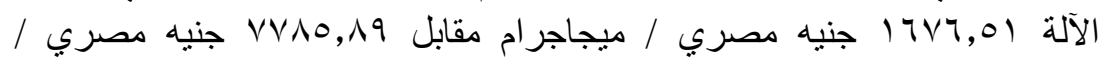
ميجاجر ام من المحصول اليدوي الجمع.

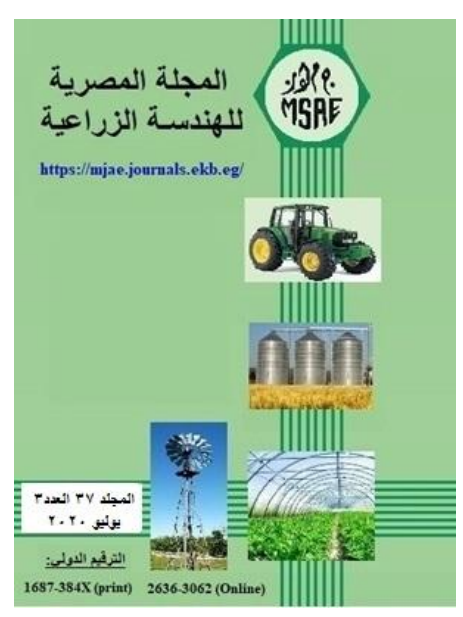

C) المجلة المصرية للهندسة الزراعية

الكلمات المفتاحية:

الكلانديو لا، قطف الكلانديو:لا، مشط

قطف 